\title{
ВНУТРІШНЯ ТОРГІВЛЯ В УСРР ПЕРШОЇ ПОЛОВИНИ 1930-Х РОКІВ (ЗА МАТЕРІАЛАМИ НІМЕЦЬКИХ КОНСУЛЬСТВ)
}

Анотація: Розкрито важливість звітів іноземних дипломатичних установ в Украӥнській СРР на прикладі консульських установ Німеччини. Подано баченнями німецькими дипломатами стану внутрішньої торгівлі в радянській Україні, ролі системи Торгсін в експропріації радянських громадян «по-більшовицьки». Наведено сприйняття Торгсіну зарубіжними благодійниками, які вбачали у даній організації систему обману та спекуляції. Окремі факти свідчать про суцільні недоліки радянської системи торгівлі 1930-х років та ї̈ відірваність від законів економіки.

Ключові слова: німецьке консульство, дипломатичний звіт, торгівля, УСРР, Торгсін, Голодомор 1932-33 рр.

Все частіше українська історична наука звертається до неспецифічних для вітчизняного дослідника груп джерел. До такої групи ми відносимо звіти дипломатичних установ (посольств, консульств, агентств). Як відомо, одним із завдань іноземного представництва було складання звітів про ситуацію на підпорядкованій території. Ці звіти часто були досить детальними й охоплювали різні сторони життя суспільства та держави: політико-економічний стан, розвиток культури й освіти, військова сфера тощо. При цьому, як точно зазначає український історик В. Ададуров, «фіксувалися найважливіші тенденції, події та постаті, а іноді й унікальні розмови з останніми» і, таким чином, «дипломати не лише інформували свої уряди, а й залишили історикам джерела». При цьому, не дивлячись на певний суб’єкивізм умовиводів і ремарок у даних звітах, вони є неперевершеним й оригінальним джерелом для вивчення минулого України.

У XXI ст. українські історики для вивчення складних подій міжвоєнного періоду 1918-1939 рр. стали залучати вищезазначену групу джерел. Переважно увага була зосереджена на одному із ключових і суперечливих напрямків дослідницького інтересу - проблемі Голодомору 1932-33 років. Серед таких праць хотілося б відзначити А. Граціозі², В. Марочка ${ }^{3}$, В. Даниленка ${ }^{4}$, Я. Брускі ${ }^{5}$, Л. Вовчук і С. Корновенка ${ }^{6}$. Більш ширшими є вве-

\footnotetext{
• Тригуб Олександр Петрович - доктор історичних наук, професор, завідувач кафедри міжнародних відносин та зовнішньої політики Чорноморського національного університету імені Петра Могили (м. Миколаїв, Україна); ORCID: https://orcid.org/0000-0003-0610-1702; e-mail: alextrigub@ukr.net

${ }^{1}$ Ададуров B. (ред.). Архіви консульських установ іноземних держав як джерело до вивчення української істоpiї XIX - початку XX століть. Львів: Вид-во Українського католицького університету, 2017. С. 11.

${ }^{2}$ Граціозі А. (упоряд.). Листи з Харькова. Голод в україні та на Північному Кавказі в повідомленнях італійських дипломатів, 1932-1933 роки. Харків: Вид-во ФОЛІО. 2007. 255 с.

${ }^{3}$ Марочко В. Німецькі дипломати і голодомор 1932-1933 рр. в Україні // Київські історичні студії. 2015. № 1. С. 62-66.

${ }^{4}$ Даниленко В. (ред.). Голодомор 1932-1933 рр. в Україні за документами ГДА СБУ: Анотований довідник / В.М. Даниленко (відп. упоряд.), Л.Л. Аулова, В.В. Лавренюк. Львів: Центр дослідження визвольного руху, 2010. C. 277-306.
} 
дені до наукового обігу документи німецьких консульств у Харкові й Одесі, опубліковані та прокоментовані А. Кудряченком ${ }^{7}$ та О. Бажаном ${ }^{8}$. Натомість, не дивлячись на широту охоплення звітами соціально-економічного та політичного життя УСРР, головна увага більшості дослідників була звернена саме на проблему голоду, колективізації та стану селянства. Отже проблема внутрішньої торгівлі залишилася, у деякій мірі, поза увагою дослідників, що й сформулювало основну дослідницьку мету автора - показати внутрішню торгівлю в УСРР і місце в ній Торгсінуํ, як однієї з ключових їі складових.

Відразу зазначимо, що виявити документи з аналізом чи згадкою про внутрішню торгівлю та її оцінку за 1930-31, 1935 рр. нами не вдалося. Наявний комплекс звітної документації консульств в УСРР (опублікованих і представлених у Галузевому держархіві Служби безпеки України) зосереджується, переважно, на періоді 1932-1936 pp. В окремих досить розлогих звітах (наприклад, «Річний звіт консульства Німеччини у Харкові за 1933 р.») питання торгівлі взагалі не піднімається (головна увага зосереджена на фактах голоду, колективізації та стані колгоспів, промисловому потенціалі тощо) ${ }^{10}$. Отже завданням було виявити будь-який матеріал щодо внутрішньої торгівлі, який став би доповненням до вже існуючих розвідок у цій науковій площині.

Як відомо, 1929 р. радянське керівництво взяло курс на форсовану індустріалізацію, для «побудови матеріально-технічної бази соціалізму». Оскільки фінансових ресурсів більшовики не мали, а іноземні інвестиції залучити не мали змоги, то важка промисловість почала швидкими темпами розвиватися за рахунок перекачування у неї коштів, що нагромадилися у сільському господарстві, легкій промисловості, торгівлі й інших галузях ${ }^{11}$. Перша п'ятирічка (1928/29 - 1932/33 рр.) супроводжувалася масовою та примусовою колективізацією, розкуркуленням, згортанням вільної торгівлі, Голодомором, демпінговим вивозом українського зерна за кордон та іншими негативними явищами.

У результаті сталінського стрибка в індустріалізації України, як і взагалі в СРСР, поглибилися диспропорції у розвитку господарства, зріс дефіцит товарів широкого вжитку, посилилась інфляція. 3 середини 1928 р. діяла карткова система розподілу продуктів, а в 1930 р. було створено Торгсін, одним із завдань якого стало «добровільне» вилучення у

\footnotetext{
${ }^{5}$ Bruski J.J. Hołódomor 1932-1933. Wielki Głód na Ukrainie w dokumentach polskiej dyplomacji i wywiadu. Warszawa: Polski Instytut Spraw Międzynarodowych, 2008.778 p.

${ }^{6}$ Вовчук Л., Корновенко С. Голодомор 1932-1933 рр. очима іноземних дипломатів // Емінак. 2019. № 4 (28). C. 71-82. DOI: https://doi.org/10.33782/eminak2019.4(28).343

${ }^{7}$ Кудряченко А. (ред.). Голодомор в Україні 1932-1933 років. За документами Політичного архіву Міністерства закордонних справ Федеративної Республіки Німеччина / Упоряд. вступ. стаття, пер. 3 нім. А.І. Кудряченко; Передмова Ю.Г. Рубана. Київ: НІСД, 2008. 340 с.

${ }^{8}$ Бажан О. Погляд з Харкова. Суспільно-політичне життя в Українській РСР в середині 1930-х років очима німецьких дипломатів // Сумський історико-архівний журнал. 2012. №16-17. С. 91-112; Бажан О. Погляд 3 Одеси. Суспільно-політичне та економічне життя на Півдні України у першій половині 1930-х років очима німецьких дипломатів // Південний Захід. Одесика. Історико-краєзнавчий науковий альманах. 2016. Вип. 20. C. 179-199.

${ }^{9}$ Торгсін, або Торгзін - Всесоюзне об’єднання по торгівлі з іноземцями (рос. Всесоюзное объединение по торговле с иностранцами). Радянська організація, що займалася обслуговуванням гостей 3-за кордону та радянських громадян, що мали «валютні цінності» (золото, срібло, дорогоцінні камені, предмети старовини, готівкову валюту), які вони могли обміняти на харчові продукти або інші споживчі товари.

${ }^{10}$ Див.: Галузевий державний архів Служби безпеки України (ГДА СБУ). Ф. 13. Оп. 1. Спр. 161. Т. 2. Арк. 39-60.

${ }^{11}$ Лановик Б.Д. (ред.). Економічна історія України і Світу. Київ: «Вікар», 1999. С. 620-621.
} 
постійно нужденного населення заощаджень у «валютних цінностях» за спекулятивно низькими цінами.

Звісно, що в таких умовах ніякого нормального розвитку внутрішньої торгівлі бути не могло. Це відмічав і німецький консул в Одесі Фрідріх Рот у своєму річному звіті за 1933 р.: «Внутрішня торгівля не розвивалася. Як і раніше, важко чи взагалі неможливо купити найпростіші предмети щоденного ужитку. Гас, наприклад, протягом багатьох місяців неможливо було дістати навіть за картками, також і преміювання колгоспникам за відпрацювання зверх норми одягом і чоботами свідчило про “дефіцитність” цих товарів» ${ }^{12}$.

Помітне місце у підтримці внутрішньої торгівлі через систему магазинів «Торгсін», займали перекази з-за кордону. Так, з весни 1933 року через одне лише німецьке консульство шляхом воєнних позик було переведено 50000 марок $^{13}$.

Не виправдовувала себе створена у 1929 р. мережева компанія «Інтурист», яка повинна була залучити «туристичну валюту»: «3 весни цього року, «Інтурист», на який ще два роки назад покладали завищені надії, мало розвивався. Будівництво великого готелю для Інтуриста, яке було розпочате на той час в Одесі, не продовжувалося до 1933 року. Навіть зниження інтуристських цін (на проїзд), мабуть не особливо просунуло справу Інтуриста» ${ }^{14}$. Отже пожвавити торгівлю за допомогою залучення туристів 3-за кордону на той час не вдалося.

Погано сприяла торгівлі й прогресуюча інфляція. На початку 1933 р. знецінення радянської валюти продовжувалося. Як вказував Ф. Рот у своєму звіті, влітку співвідношення золотого карбованця до радянського досягало приблизно 1 : 50. Це співвідношення особливо яскраво проявлялося у торгсінівських і комерційних цінах на хліб і цукор у порівнянні $з$ цінами у державних магазинах. У співставленні золотого обчислення карбованця (Торгсін, Інтурист, зовнішня торгівля) зі знеціненим інфляцією та зниженим приблизно на 2\% радянським карбованцем, яскраво було видно, що «твердження про те, що у Радянському Союзі немає інфляції, що інколи з'являлося у радянській пропаганді за кордоном - це чиста фікція». Подальшому падінню паперового карбованця перешкодив врожай 1933 р., що яскраво відобразилося на чорній біржі. Окрім того, перешкоджала галопуючій інфляції і нестача оборотних коштів, що виражалося у періодичному затягування видачі заробітної плати ${ }^{15}$.

При цьому консул звертає увагу на те, що набирає обертів торгівля через мережу Торгсін. «Торгсінівська торгівля продовжувала розвиватися. Торгсінівські ціни, взагалі, знизилися, але все ж перевищували ціни світового ринку, за винятком окремих предметів (сірників, полотна), причому торгсінівські товари не першокласні. Число торгсінівських магазинів знову збільшилося, так що навіть невеликі районні центри, як правило, мають “Торгсін”. Товарообіг цих магазинів ймовірно значний. 3 одного боку, населення продавало усі предмети, що мали яку-небудь цінність, навіть обручки, з іншого боку - збільши-

\footnotetext{
${ }^{12}$ ГДА СБУ. Ф. 13. Оп. 1. Спр. 161. Т. 7. Арк. 16. Варіант перекладу безпосередньо з німецької мови див.: Кудряченко А. (ред.). Голодомор в Україні 1932-1933 років... С. 228.

${ }^{13}$ ГДА СБУ. Ф. 13. Оп. 1. Спр. 161. Т. 7. Арк. 16.

${ }^{14}$ Ibidem.

${ }^{15}$ ГДА СБУ. Ф. 13. Оп. 1. Спр. 161. Т. 7. Арк. 18-19. Варіант перекладу безпосередньо з німецької мови див.: Кудряченко А. (ред.). Голодомор в Україні 1932-1933 років... С. 230-231.
} 
лися перекази 3-за кордону» ${ }^{16}$. Це й не дивно, адже на 1932-33 рр. торгівля через Торгсін, як свідчать сучасні дослідження, мала найбільший попит, оскільки населення віддавало останні цінності для спасіння життя від голодної смерті. У записці Ф. Рота від 6 лютого 1933 р. зазначалося, що «селянин віддає останнє, щоб купівлею продуктів у Торгсіні продовжити своє існування» ${ }^{17}$.

Разом $з$ тим, документи німецьких дипломатичних установ відзначають стабільність недоліків у роботі системи Торгсін. Так у лютому 1933 р. німецьке консульство в Одесі отримало від МЗС Німеччини за 7 лютого 1933 р. записку під назвою «Про нові негаразди з торгсінівськими переказами». У ній зокрема говорилося:

«За останні тижні з України надходять відомості про те, що в осіб, які купували у Торгсіні продукти за отриманим на Торгсін переказом, ці продукти відбираються для виконання плану хлібозаготівлі. Такі відомості викликали велике обурення серед закордонних благодійників і паплюжать Торгсін, про який радянська влада рекламувала в усіх країнах як про абсолютно надійне підприємство...

У нейтральних країнах також виражають обурення з цього приводу. Наведемо витяг 3 листа шанованого швейцарського благодійника (Відмайєр у Рейнаху, 28 січня 1933 р.), який пише:

"Збирався зробити Вам знову велике доручення, але при існуючому становищі у мене пропало будь-яке бажання у цьому. Я вважав, що Торгсін існує для того, щоб мешканці закордону могли надавати допомогу своїм друзям у СРСР, але якщо отримане у Торгсіні повністю або частково у них відбирають, тоді втрачається увесь сенс Торгсіна, збудованого на величезному обмані".

Із САСШ ${ }^{18}$ надходять такі ж відгуки.

Якщо подібні речі робляться з торгсінівськими переказами, то можна очікувати, що посилки також будуть відніматися у голодуючих. За кордоном не задовольняються тим, що отримувачі не виконали податку, в оплату якого відбирається отримана 3-за кордону допомога. Такими методами втягують інші країни у виконання господарської програми СРСР. За кордоном прекрасно знають, що стягувані податки є просто нездійсненними вимогами.

Вважаючи на те, що скромна допомога німцям у СРСР стоїть під загрозою, на це буде звернено увагу Радянського Посольства і представника Держбанку, що знаходиться на даний час у Берліні. Я прошу узгодити дійсне становище в $\mathrm{HK} \mathrm{C}^{19}$, не задовольняючись відповіддю, що це, начебто, одиничний випадок і що винні у цьому окремі, занадто ревні, місцеві організації» ${ }^{20}$.

Для кращого розуміння сутності даної скарги хотілося б навести лист благодійника Відмайєра до Дирекції Східного гарантійного і кредитного банка (Берлін, 28 січня 1933 р.), про який йде мова у записці німецького МЗС.

«Як Вам можливо відомо, я робив перекази на Торгсін через Вашу установу. У випадку, якщо мої перекази представляють інтерес для Вас чи для Вашого Уряду, я вважаю своїм

\footnotetext{
${ }^{16}$ ГДА СБУ. Ф. 13. Оп. 1. Спр. 161. Т. 7. Арк. 16. Варіант перекладу безпосередньо з німецької мови див.: Кудряченко А. (ред.). Голодомор в Україні 1932-1933 років... С. 228.

${ }^{17}$ ГДА СБУ. Ф. 13. Оп. 1. Спр. 161. Т. 7. Арк. 24.

${ }^{18}$ Північноамериканські Сполучені Штати (рос. Северо-Американские Соединенные Штаты). - О.T.

${ }^{19}$ Мається на увазі Народний комісаріат закордонних справ СРСР. - О.Т.

${ }^{20}$ ГДА СБУ. Ф. 13. Оп. 1. Спр. 161. Т. 7. Арк. 35-36.
} 
обов'язком повідомити Вам наступне: мені повідомили з двох місць України про те, що у людей, які купляли у Торгсіні продукти на прислані з-за кордону гроші, ці продукти відбирають у сплату невиконаних податків, якими їх обкладають у нездійснених межах. Я дозволю навести тут буквально слова одного довіреного мені чоловіка, людини розсудливої, не підбурювача. У нього 10 душ сімї̈. Він говорить: "У даний час ми знаходимося у дуже важкому становищі. Діти наші працювали в артілі і тепер повинні повернути хліб, який діти їли під час своєї важкої роботи. Ми повинні внести 82 кг хліба та 47 кг м'яса, яке ми не бачимо вже протягом 3-х років. Я вліз у борги, розраховуючи на обіцяний Вами переказ на Торгсін”.

Ми, швейцарці, не дурні й усвідомлюємо свої вчинки. Подвійну гру я не визнаю, я можу приймати участь у справі, яка грунтується на лояльності та чесності. Якщо росіяни вважають можливим по відношенню до своїх підданих грати комедію у Торгсін, то з нами, прямими швейцарцями, цей номер не пройде. Якщо Торгсін заснований для виконання якихось таємних цілей, то це нечесно. Це вже другий випадок, про який мені стало відомо, що торгсінівські продукти відбирають для виконання плану хлібозаготівель.

Я збирався зробити Вам знову велику пропозицію, але при існуючому становищі у мене зникло будь-яке бажання до цього. Я вважав, що Торгсін існує для того, щоб ті, хто проживає за кордоном, могли надавати допомогу своїм друзям в СРСР. Але якщо обране ними у Торгсіні повністю чи частково у них відбирається, тоді втрачається увесь сенс Торгсіну, побудованого на величезному обмані...

У подальшому, якщо до мене надійдуть подібні відомості, то можете бути впевненні і Ви, і панове у Москві, що я не тільки припиню переказувати на Торгсін, але й попіклуюся про те, щоб уся Швейцарія довідалася про брехливі прийоми Торгсіна» ${ }^{21}$.

Ми бачимо, що зловживання у системі Торгсіну не лише шкодили міжнародній репутації СРСР і загалом більшовицькому урядові, а й могли привести до припинення і цього джерела для спасіння голодуючого населення країни.

Говорячи загалом про благодійництво, то організації допомоги, що користувалися послугами Торгсіна, існували окрім Німеччини, також в Америці, Швейцарії та Голландіiї2 . А. Кудряченко у вступній статті до вказаної вище праці, зазначав, що лише у Німеччині допомогою голодуючим в УСРР опікувалися організації «Брати у скруті», «Фаст і Бріліант», «Комісія 3 пересилання пакетів до СРСР», «Центральний комітет німців Чорномор'я», «Союз закордонних німців» тощо. Допомога надходила через Торгсін, поштовими переказами по 5-10 марок, пакетами, бандеролями з продуктами, посівним насінням тощо. При цьому звіт Одеського консульства зазначав, що німців-колоністів «примушують відмовлятися від цієї допомоги “добровільно” »" .

Глибоким аналізом серед дипломатичних звітів вирізняється доповідна записка аташе 3 сільськогосподарських питань посольства Німеччини у Москві Отто Шиллєра від 20 серпня 1934 р. під назвою «Продовольче становище в Радянському Союзі» . $^{24}$. Шиллєр був знаний фахівець с аграрної справи, що був прикріплений до німецького посольства. У 1933-34 рр. він здійснив спеціальну автомобільну поїздку на 10000 км 3 тим, щоб скласти

\footnotetext{
${ }^{21}$ ГДА СБУ. Ф. 13. Оп. 1. Спр. 161. Т. 7. Арк. 37-38.

${ }^{22}$ ГДА СБУ. Ф. 13. Оп. 1. Спр. 161. Т. 7. Арк. 16. Варіант перекладу безпосередньо з німецької мови див.: Кудряченко А. (ред.). Голодомор в Україні 1932-1933 років... С. 228.

${ }^{23}$ Кудряченко А. (ред.). Голодомор в Україні 1932-1933 років... С. $22-23$.

${ }^{24}$ ГДА СБУ. Ф. 13. Оп. 1. Спр. 161. Т. 11. Арк. 21-28.
} 
власне враження про становище у найважливіших сільськогосподарських регіонах СРСР, проаналізувати ситуацію 3 продовольством і запропонувати оцінку перебігу подій ${ }^{25}$.

Щодо торгівлі та ситуації на ринку О. Шиллєр відзначав:

«Значно підтримало голодуюче населення започаткування продажу комерційного хліба. Перед хлібними лавками стояли величезні черги. Ціни на комерційний хліб були всюди однакові: чорний хліб - 1,50, сірий - 2 крб. і білий - 3 крб. У південних і південносхідних областях комерційний хліб продавався тільки у великих містах. У маленьких містах торгівлю комерційним хлібом або зовсім не починали, або ж вона швидко припинялася у зв'язку з малими запасами. В областях, де у зв'язку з поганим врожаєм ринкова торгівля була поганою, сільське населення здійснювало тривалі поїздки для купівлі хліба. У тих областях, де у минулому році був хороший врожай, ринкова торгівля стала поповнювати комерційну торгівлю. Багато колгоспів та одноосібників продавали свої хлібні залишки на невеличких базарах. У порівнянні з минулим роком, ціни були відносно низькі... У середньому на борошно встановилися у поточному році (мова йде, ймовірно, про 1934 р. - 0.T.) наступні ціни: житне борошно - 35-40 крб. і пшеничне - 60-70 крб. за пуд, у той час, як у минулому році за пуд пшеничного борошна платили більше 100 руб., а в деяких містах і до 250 крб.

В одній урядовій постанові, що мала на меті обгрунтування підвищення цін на хліб, було сказано, що на вільних ринках ціни на все будуть підвищені. У дійсності, на багатьох ринках відвіданих областей, підвищення цін не відбулося. На початку липня, у зв'язку 3 початком збору врожаю, на ринках була заборонена торгівля зерном і борошном» ${ }^{26}$.

Про покращення внутрішньоторгівельного обороту зазначало й німецьке консульство в Одесі у звіті за 1934 р., що був направлений посольству Німеччини у Москві: «Внутрішня торгівля зросла, але вона не може задовольнити попит. Крім того ця торгівля розвивається через систему так званих комерційних крамниць, високі ціни в яких зовсім не відповідають низьким середнім заробіткам більшості населення» ${ }^{27}$.

Покращення ситуації у торгівлі пояснювалося і зміцненням радянської грошової одиниці та монетарною політикою більшовиків: «Курс карбованця, тобто співвідношення між паперовим карбованцем і карбованцем Торгсіну у нелегальному обігу, порівняно 3 минулим роком, зріс. Це можна лише частково пояснити реальним збільшенням купівельної спроможності карбованця. Значно більшу роль у зростанні курсу відіграли, з одного боку, обмеження торгівлі через Торгсін, а з іншого - облаштування численних нових комерційних крамниць, тобто розширення можливостей придбати за карбованці необхідні товари. У невеликих населених пунктах, навпаки, низку крамниць Торгсіну було зачинено, тоді як ще наявні, в цілому, гірше забезпечені товарами, ніж раніше» ${ }^{28}$.

Особлива зацікавленість у звітах проявилася до відміни хлібних карток. 3 цього приводу німецьке посольство у Москві 6 грудня 1934 р. розіслало усім консульствам в СРСР і МЗС Третього Рейху спеціальну доповідь посла Вернера Шуленбурга з цього при-

\footnotetext{
${ }^{25}$ Кудряченко А. (ред.). Голодомор в Україні 1932-1933 років... С. 20.

${ }^{26}$ ГДА СБУ. Ф. 13. Оп. 1. Спр. 161. Т. 11. Арк. 22-23.

${ }^{27}$ ГДА СБУ. Ф. 13. Оп. 1. Спр. 161. Т. 1. Арк. 10; Бажан О. Погляд з Одеси... С. 188; Кудряченко А. (ред.). Голодомор в Україні 1932-1933 років... С. 321.

${ }^{28}$ ГДА СБУ. Ф. 13. Оп. 1. Спр. 161. Т. 1. Арк. 11; Бажан О. Погляд з Одеси... С. 189; Кудряченко А. (ред.). Голодомор в Україні 1932-1933 років... С. 322.
} 
воду $^{29}$. Коротко розкривши постанову листопадового пленуму ЦК ВКП(б) про скасування карткової системи, аналітики дипломатичного корпусу зробили низку висновків.

По-перше, «партійне керівництво не упустить можливості зобразити цю подію, як значний успіх іï̈ економічної політики та використає її для відповідної пропаганди». Таким чином, «якщо ззовні та з економічної точки зору відміну хлібних карток можна розглядати як ознаку прогресуючого економічного та внутрішньополітичного укріплення Радянського Союзу, то з соціалістичної сторони, цей захід означає крок назад, за який партія бере на себе важку за наслідками відповідальність». При цьому «переважна частина населення Радянського Союзу, а саме, селянство, все ще знаходиться у страшних злиднях, партія думає взяти відповідальність відміною карткової системи, створюючи враження всередині країни і закордоном про те, що начебто економічне становище Радянського Союзу дозволяє йому відмовитися від заходів народжених злиднями та поступитися місцем покращенню умов».

«Поряд із цим, існуюче достатнє постачання міст, промислових центрів та армії досягнуто лише за рахунок безперервної, безпощадної експлуатації сільського населення, у зв'язку з чим, користь від нового заходу обмежиться порівняно тонким прошарком населення» (у документі абзац підкреслено) ${ }^{30}$.

Отже ми бачимо, що вже по гарячих слідах німецькі аналітики робили висновки, до яких дійшли історики сучасності, проаналізувавши події того часу.

Другим висновком було те, що «з соціально-політичної точки зору, відміна карткової системи означає подальшу диференціацію населення на касти і прошарки». Під подібною диференціацією бачилося виділення серед робітників т.зв. «ударників», які не тільки будуть отримувати більші зарплати, а й користуватися різними пільгами. Подібний підхід вже «не мав нічого спільного з початковими вченням комунізму» ${ }^{31}$.

Говорячи про внутрішню торгівлю у 1935 р., то можна зауважити, що німецькі аналітики відзначали різку боротьбу з крадіжками у торгівлі, яка, як у 1935 р., так і в 1936 р., попри всі офіційні заяви уряду «не мала великого успіху». Про це свідчать факти наведені за 1936 р. (навряд чи рік раніше ситуація була кращою), що «на засіданні кооперативів [Харківської] області прийшлося визнати, що у трьох районах у центрі уваги стоять крадіжки, так, наприклад, в одній тільки Харківській офіційній союзній організації [кооперативів] встановлено розкрадання на 1 млн. карбованців» ${ }^{32}$.

Узагальнюючи викладений матеріал, можна прийти висновку, що внутрішньоторгівельний сектор німецькими дипломатичними аналітиками сприймався як складова багатьох галузей господарства СРСР і, насамперед, сільського господарства. При цьому фактичний матеріал ними добувався з різних джерел: офіційних друкованих видань, інформації від відвідувачів консульства та його інформаторів, власних спостережень від поїздок у межах консульської юрисдикції. Звісно необхідно враховувати той факт, що дипломати, маючи інший ментальний світогляд і життєвий досвід іншого соціокультурного середо-

\footnotetext{
${ }^{29}$ ГДА СБУ. Ф. 13. Оп. 1. Спр. 161. Т. 1. Арк. 58-61.

${ }^{30}$ Ibid. Арк. 60.

${ }^{31}$ Ibidem.

${ }^{32}$ Інформаційне повідомлення Генерального консульства в Харкові Посольству Німеччини у Москві про політичне становище в Харківській області в 1936 році (12 січня 1937 р.) // Бажан О. Погляд з Харкова... С. 109.
} 
вища, не були позбавлені упередженості у сприйнятті навколишньої реальності. Разом 3 тим, наведений ними фактологічний матеріал «по гарячим слідам»є не лише оригінальним джерелом українського минулого, а й безцінним свідком «живої» історії України в усьому їі різноманітті. Данні матеріали додатково підтверджують антисоціальний характер економічної політики більшовицького уряду, а здирницькі торгівельні відносини були зайвим свідченням цієї політики.

\title{
Oleksandr Trygub
}

\section{Domestic Trade in the Ukrainian SSR in the First Half of 1930s (based on materials from German Consulates)}

\begin{abstract}
Reports of diplomatic institutions (embassies, consulates, agencies) can be classified as a non-specific, but important group of sources. As you know, one of the tasks of the foreign mission was to compile reports on the situation in the subordinate territory. These reports were quite detailed and covered various aspects of the life of society and the state: the political and economic situation, the development of culture and education, the military sphere, etc.

The importance of reports of foreign diplomatic missions in the Ukrainian SSR on the example of German consulates is revealed. German diplomats present visions of the state of domestic trade in Soviet Ukraine, the role of the Torgsin system (All-Union Association for Trade with Foreigners) in the «bolshevik-style» expropriation of soviet people. Torgsin's perception by foreign philanthropists, who saw in this organization a system of deception and speculation, is given. Some facts indicate the continuous shortcomings of the Soviet trading system in the 1930s and its isolation from the laws of economics.

The author concluded that the domestic trade sector was perceived by German diplomatic analysts as a component of many sectors of the USSR' economy and, first of all, agriculture. The factual material by German analysts was obtained from various sources: official print media, information from visitors to the consulate and its informants, their own observations from trips within the consular jurisdiction. The factual material presented by them is not only an original source of the Ukrainian past, but also an invaluable witness to the «living» history of Ukraine. These materials further confirm the antisocial nature of the economic policy of the Bolshevik government, and predatory trade relations were further evidence of this policy.
\end{abstract}

Keywords: German consulate, diplomatic report, trade, Ukrainian SSR, Torgsin, Holodomor of 1932-33 